\begin{tabular}{|c|c|c|c|}
\hline Article Info & \multicolumn{2}{|r|}{ DERLEME MAKALESİ } & \\
\hline Title of Article & \multicolumn{2}{|c|}{$\begin{array}{l}\text { An Analysis on the Position and Spatial } \\
\text { Organization of the Bazaar in the Seljuk } \\
\text { and Ottoman Urban Structure in Anatolia }\end{array}$} & \\
\hline $\begin{array}{l}\text { Corresponding } \\
\text { Author }\end{array}$ & \multicolumn{2}{|c|}{$\begin{array}{l}\text { İzzettin KUTLU } \\
\text { Mardin Artuklu Üniversitesi, Mühendislik ve Mimarlık Fakültesi, Mimarlık Bölümü, } \\
\text { izzettinkutlu@artuklu.edu.tr }\end{array}$} & \\
\hline $\begin{array}{l}\text { Received Date } \\
\text { Accepted Date }\end{array}$ & \multicolumn{2}{|c|}{$\begin{array}{l}26.12 .2020 \\
20.04 .2021\end{array}$} & \\
\hline DOI Number & \multicolumn{2}{|l|}{ https://doi.org/10.35674/kent.847196 } & \\
\hline Author / Authors & $\begin{array}{l}\text { Saide Selin ERAY } \\
\text { İzzettin KUTLU }\end{array}$ & $\begin{array}{l}\text { ORCID: 0000-0001-7347-4600 } \\
\text { ORCID: 0000-0002-5546-5548 }\end{array}$ & \\
\hline How to Cite & \multicolumn{2}{|c|}{$\begin{array}{l}\text { ERAY, S. S. ve KUTLU, İ. (2021). Anadolu'da Selçuklu ve Osmanlı Kent Yapısında } \\
\text { Çarşının Konumu ve Mekânsal Kurgusu Üzerine Bir İrdeleme, Kent Akademisi, } \\
\text { Volume 14, Issue 2. Pages; 506-517 }\end{array}$} & $\begin{array}{l}\text { Kent Akademisi } \\
\text { Urban Acaderny }\end{array}$ \\
\hline
\end{tabular}

\title{
Anadolu'da Selçuklu ve Osmanlı Kent Yapısında Çarşının Konumu ve Mekânsal Kurgusu Üzerine Bir İrdeleme
}

\begin{abstract}
:
Bazaar is known as an economic pulse of a city. This study describes the emergence and stages of the bazaar in Anatolian cities by evaluating the commercial constructions of the Seljuk and Ottoman periods and their historical evolution. In order to explain bazaar and its units and functions, three bazaars are analyzed in this study. The first one is the Konya Grand Bazaar. Despite of the changes that this bazaar has undergone in diverse periods, its first foundation dates back to the Seljuk period. The Second example is in Bursa and the third one is the Istanbul Grand Bazaar in the context of Ottoman city-center development. While this study analyses the features of the bazaar in the Seljuk city morphology through literature review, it also deals with the socio-economic stages of the Ottoman Empire in various periods. Consequently, a comparison method explains how these changes has affected the characteristics of the commercial center and the bazaar in The Seljuk and Ottoman cities based on the analyzed case studies.
\end{abstract}

KEYWORDS: Bazaar, Seljuk period, Ottoman period, historical commercial constructions, Istanbul Grand Bazaar.

\footnotetext{
${ }^{1}$ Ağrı İbrahim Çeçen Üniversitesi, Patnos Meslek Yüksekokulu, Mimari Restorasyon Program1, sseray@agri.edu.tr

${ }^{2}$ Mardin Artuklu Üniversitesi, Mühendislik ve Mimarlık Fakültesi, Mimarlık Bölümü, izzettinkutlu@artuklu.edu.tr
} 


\section{ÖZ:}

Birçok kent merkezinde çarşı unsuru, kentin en önemli parçalarından biri olmaktadır ve kent ekonomisinin nabzının attığı kamusal bir mekân olarak bilinmektedir. Çarşı, sadece ticari faaliyetlerin yapıldığı bir alan olmayıp aynı zamanda üretim yapılan ve birçok farklı işlevdeki sosyal tesisi de içinde barındıran bir sistemdir. Bu sistem, genellikle şehir hayatının merkezini oluşturmaktadır. Dolayısı ile kent araştırmalarında çarşı unsuru önemli bir değer taşımaktadır. Bu çalışma, Anadolu kentlerindeki çarşı unsurunun, tarihsel sürecini inceleyerek kent dokusunda çarşının ortaya çıkışı ve geçtiği evreleri ele almaktadır. Anadolu topraklarında çarşı değişim ve gelişimini belirgin özellikleri ile yansıtmak amacıyla; Selçuklu ve Osmanlı dönemleri olmak üzere Anadolu'da önemli eserler inşa eden iki dönem karşılaştırılmıştır. Bu amaç doğrultusunda çalışmada, öncelikle Selçuklu kent sisteminde ticari merkezin oluşumuna ve çarşının bu merkezdeki önemine değinilmiştir. Selçuklu döneminin ardından, kentlerde ticari sistemin ve çarşı kültürünün Osmanlı devleti ile beraber uğradığı değişimler değerlendirilmiştir. Çarşı ve içinde bulundurduğu birimleri ve işlevlerini açıklamak adına üç örnek çarşı kısaca irdelenmiştir. İlk örnek, kuruluşunun temelleri Selçuklu dönemine dayanan, Konya kentinin merkezinde bulunan ve farklı dönemler içerisinde değişimlere uğramasına rağmen halen varlığını sürdüren Konya Kapalı çarşı ve bedestenidir. İkinci örnek, Bursa kentinde bulunan kapalı çarşıdır. Son örnek ise Osmanlı kent-merkez gelişimi bağlamında dünyanın en büyük çarşılarından biri olan İstanbul Kapalıçarşı'sıdır. Çalışmanın sonucunda, çarşı unsurunun Selçuklu kent morfolojisindeki yeri ve özellikleri ile birlikte Osmanlı döneminde geçirdiği sosyo-ekonomik evreler ortaya çıkarılmıştır. Dönem içerisinde değişimlerin karşılaştırıldığı çalışmada, geçiş süreçlerinde ticari merkez ve çarşı özelliklerinin nasıl etkilendiği tartışılmıştır.

ANAHTAR KELIMELER: Çarşı, Selçuklu dönemi, Osmanlı dönemi, tarihi ticari yapılar, İstanbul Kapalıçarşı.

\section{"Anadolu'da Selçuklu ve Osmanlı Kent Yapısında Çarşının Konumu ve Mekânsal Kurgusu Üzerine Bir İrdeleme"}

\section{GíRiş:}

Anadolu toprakları, konumu itibariyle ticari açıdan önemli geçiş yolları üzerinde yer almaktadır. Özellikle Avrupa, Asya ve Uzakdoğu'yu birbirine bağlayan bu önemli yollar, Anadolu topraklarında, ulusal ve uluslararası ticari kaynakların ülke ekonomisindeki öneminin artmasına neden olmuştur. İpekyolu ve Baharat Yolu'nun önemli birçok bölümünün bu topraklardan geçmesi, bölgede hüküm sürmüş olan Selçuklu ve Osmanlı devletlerine hem ticari potansiyel hem de stratejik önem kazandırmıştır. Uluslararası ticaretin ülkelerin ekonomisi için önemli bir kaynak olduğunun farkına varan devlet adamları, ticari faaliyetlerin; daha güvenli, daha kolay, daha rahat gerçekleştirilebilmesine ve transit geçişlerin kalite ve güvenliğine önem vermişlerdir. Bu nedenle ülkeler, ticari yol güzergahlarında menzil ve kervansaraylar; şehirlerin içerisinde de han, bedesten ve çarşı gibi önemli ticari alanlar oluşturmuştur (Tabakoğlu, 1985) . Bu ticari alanların en önemlisi, kent ekonomisinin kalbi olan çarşılar ve onların işlevini destekleyen birimlerdir. Özdeş (1998), çarşıyı iki tarafında dükkânların konumlandığı alışveriş yapılan üstü açık veya kapalı mekanlar olarak tanımlamaktadır (Özdeş, 1998). Çarşı kuruluşunun ilk evresi, kent kapılarında kurulan pazarlardır (Tanyeli, 1986). Açık havada yer alan haftalık çarşı veya panayır biçiminde olan alım satım yeri olarak bilinen pazarlar, 16.yüzyıla kadar çarşı ile eş anlamlı olarak kullanılmıştır (Cezar, 1983).

Selçuklu ve daha sonra Osmanlı dönemi çarşıları, geleneksel Türk ve İslam şehircilik kültürünün etkisiyle şekillenen kentlerin belirli bölgelerinde konumlanmıştır. Konumlanmada sırasında kent içindeki kale veya kent surları, ticaret yolu güzergahları, sosyal ve kültürel bölgelere yakınlık gibi faktörler önem taşımıştır (Kejanlı, 2010). Çarşılar çoğunlukla bu faktörlerin birinin, birçoğunun veya tamamının etkilediği bölgelerde gelişim göstermiştir.

Çarşı, ticaretin yapıldığı bir alan olmasının yanı sıra pek çok sosyal tesis ve üretimi de içeren bir sistemden oluşmaktadır. Çarşı sisteminin merkezinde, Selçuklu ve Osmanlı dönemlerinde bedestenler yer almıştır ve bedestenlerin çevresinde dükkânlar belirgin bir sıra dizisinde tasarlanmıştır. Satılan ürünün değeri arttıkça dükkân bedestene daha yakın mesafede konumlandırılmıştır. Oluşan bu ticari çekirdeğin çevresindeki ilk çemberi, hanlar oluşturmuştur. Daha sonra değeri daha düşük olan dükkânlar ve zanaat bölgelerine; son olarak en diş çeperde ise deri atölyeleri ve pazarlara yer verilmiştir (Cezar, 1983; Aktüre, 1987).

$\mathrm{Bu}$ araştırma, kentin temel unsurlarından olan çarşıların; Anadolu kent yapısında Selçuklu devleti döneminde oluşma şekli ve bu oluşumu etkileyen etkenlere değinmiş ve daha sonraki dönemde Osmanlı devletinin farklı zaman dilimlerinde ekonomik, sosyal vb. değişimler ile beraber ne tür değişim ve dönüşümlerden geçtiğini tartışmaktadır. 
Çalışmada; öncelikle çarşı ve kent gelişimi üzerine yönelik günümüze kadar yayınlanmış olan yerli-yabancı kitaplar, makaleler, tezler, sempozyum çıktıları, internet kaynakları araştırılmış ve konu hakkında mevcut çalışmalar incelenmiştir. Kentlerde çarşı alanlarının ortaya çıkışı ve gelişimi incelenmiş; çarşı kurgusu kavramı irdelenmiştir. Anadolu topraklarında çarşı değişim ve gelişimini belirgin özellikleri ile yansıtmak amacıyla Selçuklu ve Osmanlı dönemleri olmak üzere Anadolu'da önemli etkileri olan iki dönem karşılaştııılmıştır. Bu amaca ve karşılaştırmaya yönelik, dönemsel olarak kent sisteminde çarşı ve gelişiminin kavramsal çerçevesi belirlenerek ekonomik, sosyal, çevresel boyutları saptanmış, örnekler ile detaylandırılmışıır. Çalışma sonucunda, Anadolu topraklarında başlayan ve günümüzde halen kent merkezinin nabzını oluşturan çarşıların, mekansal kurgusunun değişimini ve gelişimini ortaya çıkarmak hedeflenmiştir. Çalışmanın çarşı konusunda yapılacak olan yeni çalışmaları destekleyici olması beklenmektedir.

\section{Selçuklu Kent Sisteminde Çarşı ve Gelişimi}

Türklerin, 9. ve 13. yüzyıllar arasında Orta Asya'dan Anadolu'ya doğru göç hareketleri sürecinde farklı medeniyetlerle karşıllaşması, Orta Asya kent yaşamına ait kültürlerinin oluşmasına ve gelişmesine neden olmuştur. Horasan, Maveraünnehir ve Irak bölgelerinde yaygın olan İran-İslâm kültürü ve Anadolu'da hâkim olan Yunan-Roma kültürü yeni kurulan Selçuklu devletini her anlamda etkilemiştir. Selçuklu kültürü, sanatı, mimarisi ve kent yapısı tüm bu kültürlerin karşılıklı etkileşiminin bir ürünü olarak tanımlanabilmektedir (Özcan, 2006).

Türklerin karşılaştıkları ilk topluluk İranlılar ve geliştirdikleri yüksek düzeyde medeniyet olmuş ise de Selçuklu kentinin oluşumunda, Anadolu yerlilerinin de büyük payı bulunmaktadır. Bu durum Selçuklu kentlerinde, yerleşim düzeni ve merkez çekirdeğin düzenlenmesinde Horasan ve Türkistan'dakilerle ortak birçok özelliğe sahip olmasından anlaşılmaktadır (Tanyeli, 1986).

Ekonomik gelişmenin temelini oluşturan transit ticaret, 13. yüzyılda Selçuklu dönemindeki Anadolu kentlerinde de önemsenmeye ve gelişmeye başlamıştır. Selçuklu devleti topraklarında, geniş bir ticaret yol ağı geliştirilmiştir ve çeşitli uluslararası önemli yol ağ sistemine bağlanmıştır. Kervan ticaretinin gerektirdiği üzere önemli merkez noktaları dışında, güzergâh üzerinde bulunan küçük yerleşimler de büyümüştür. Ayrıca kervansarayların inşa edilmesi sayesinde yeni ticari merkezler de oluşmuştur (Özcan, 2010). Selçuklu kent yapısında, kervansaray gibi İslam kent tipini oluşturan "cami, pazar ve hamam" öğeleri de benimsenmiş ve Orta Asya kent tipini oluşturan, "iç kale, şehristan ve rabad" unsurlarıyla birleştirmişlerdir. Diğer önemli kent bileşenleri olan "mahalle, bedesten ve çarşılar", İslam sonrası Türk şehirlerinin en ayırt edici özellikleri olarak şehrin diğer parçalarını oluşturmuştur (Yenen, 1987). Türklerden önce ise Anadolu kentlerinin ana unsurları kilise, manastır ve ticaret yapılarından oluşmuştur. Selçuklu Dönemi ile birlikte, Bizans kültürüne Türk, İran, Arap ve Anadolu yerel kültürleri eklenmiştir ve farklı nitelikleri beraber barındıran yapılar ve kentler ortaya çıkmıştır. Bu dönemde çok sayıda yol, kervansaray, köprü gibi çeşitli önemli yapılar inşa edilmiştir.

Selçuklu kent içinde, ticari alanların başında gelen hanlar; çoğunlukla çarşı merkezlerinde yer almış ve dükkân-atölyeimalathane işlevi görmüş, dolayısıyla kent ekonomisi için önemli bir yere sahip olmuştur. Çarşının yoğun kullanılan bölümlerinin dışındaki hanlar ise otel işlevinde kullanılmıştır. Selçuklu kentlerinde ticari birimlerle ilişkili günümüze kadar ulaşan çok fazla yapı bulunmaması nedeniyle bu tarz yapıların dayanıklılı̆̆ı yüksek olmayan malzemelerden inşa edildiği tahmin edilmektedir (Yılmazçelik, 1995). Arap fetihlerinden önce sur dışında olan kentin ticari merkezi, Selçuklu döneminde sur içine alınmış; pazaryerleri ise bu dönemde de sur dışında kalmıştır. Selçuklu döneminin ilk zamanlarında, iç kaleler sadece dinsel veya yönetsel törenler ve savaş zamanlarında sığınma alanı olarak kullanılan yerler olmasına rağmen, ilerleyen dönemlerde anıtların yükseldiği ve yöneticilerin yaşadığı alanlar olarak da kullanılmıştır. Ayrıca sur dışında kalan pazar yerleri de sonraki dönemlerde dıştan gelen tehditler sonucunda sur içine alınmıştır (Cezar, 1983).

Anadolu Selçuklu kentlerinde ticari faaliyet merkezi olarak hizmet veren çarşı ve pazarların mekansal ve fonksiyonel organizasyonunda, aşağıdaki üç temel unsurun etkili olduğu söylenebilir:

- Dini yapıların kentin toplanma merkezleri işlevini de üstlenmesi sonucu çarşılar da genelde bu yapıların yakınında şekillenmiştir.

- Çarşılar, kentlerin giriş-çıkış noktalarını belirleyen kent kapılarının yakınında konumlandırılmıştır. 
- Alım-satımı yapılan herhangi mal ve ürün birleşimlerinin doğurduğu mekânsal gereksinimler sonucu çeşitli çarşılar kurulmuştur (Özcan, 2005).

\subsection{Selçuklu Döneminde Merkez-Çarşı Gelişimi}

Selçuklu devleti döneminde kurulan ticari merkezler; imalathane, hanlar, çarşı ve pazarlardan oluşmuştur. Ticari mekânlar genellikle sokak düzeninde veya sıra şeklinde konumlandırılan dükkânlar halinde yapılmıştır. Bazı kentlerde ise tek kitle halinde belirli ekonomik faaliyetler yapan sınıfların bir arada örgütlendiği ticari mekân oluşumlarına rastlanılmıştır (Tanyeli, 1986). Selçuklu dönemi vakıf-name kayıtlarında, demirciler, bakırcılar, kunduracılar, bıçakçılar, aşçılar, attârlar vb. çarşıların yansıra buğday veya at pazarı gibi belirli bir faaliyet alanına ayrılmış çarşıların olması; Anadolu Selçuklu kentlerinde aynı tür faaliyetlerde bulunan esnaf ve sanatkarların ortak yerlerde örgütlenebildiğini göstermektedir (Özcan, 2010). Konya bedesten ve çarşısı bu konuda örnek gösterilebilir. Uzun yıllar Selçuklu devletine başkentlik yapan bu kentin tarihi çarşısının temelleri, Selçuklu dönemine dayanmaktadır.

\subsection{Konya Bedesten Çarşısı}

Konya Kapalı Çarşısı, Alaaddin Tepesi'nin doğusunda Mevlâna Caddesi üzerinde konumlandırılmış Konya'nın en eski ticaret merkezi ve en önemli tarihi mekanlarından biridir. Bedesten ve çevresindeki birtakım yapılar ile Selçuklulara kadar uzanan bir geçmişe sahip olan çarşı, o dönemde şehir surlarındaki 12 kapıdan biri olan At Pazarı Kapısı çevresinde inşa edilmiştir (Şekil 1). Selçuklu döneminde başlayan ve Osmanlı döneminde de devam eden şehirciliğinin ana kuralı, kentin dinî ve ticarî merkezlere yakın kurulması ve kentin bu nüveler etrafından gelişmeye başlamasıdır. Dinî merkez birçok önemli kent örneğinde ulu camidir. Ticari yapılar ise yeni Türkleşen her kentte ilk kurulan tesislerinden olmuş ve bu yapı türünün en önemli unsuru olarak da bedestenler inşa edilmiştir. Bedesten, sağlam yapısı ile tüccarların değerli eşyalarını/mallarını koruyan önemli bir yapı türü olarak çarşının ana çekirdeğini oluşturmuştur. Şekil 2'de Selçukluların en önemli kentindeki bedesten ve çevresinde ki yapıları göstermektedir (Tutal ve Topcu, 2018).

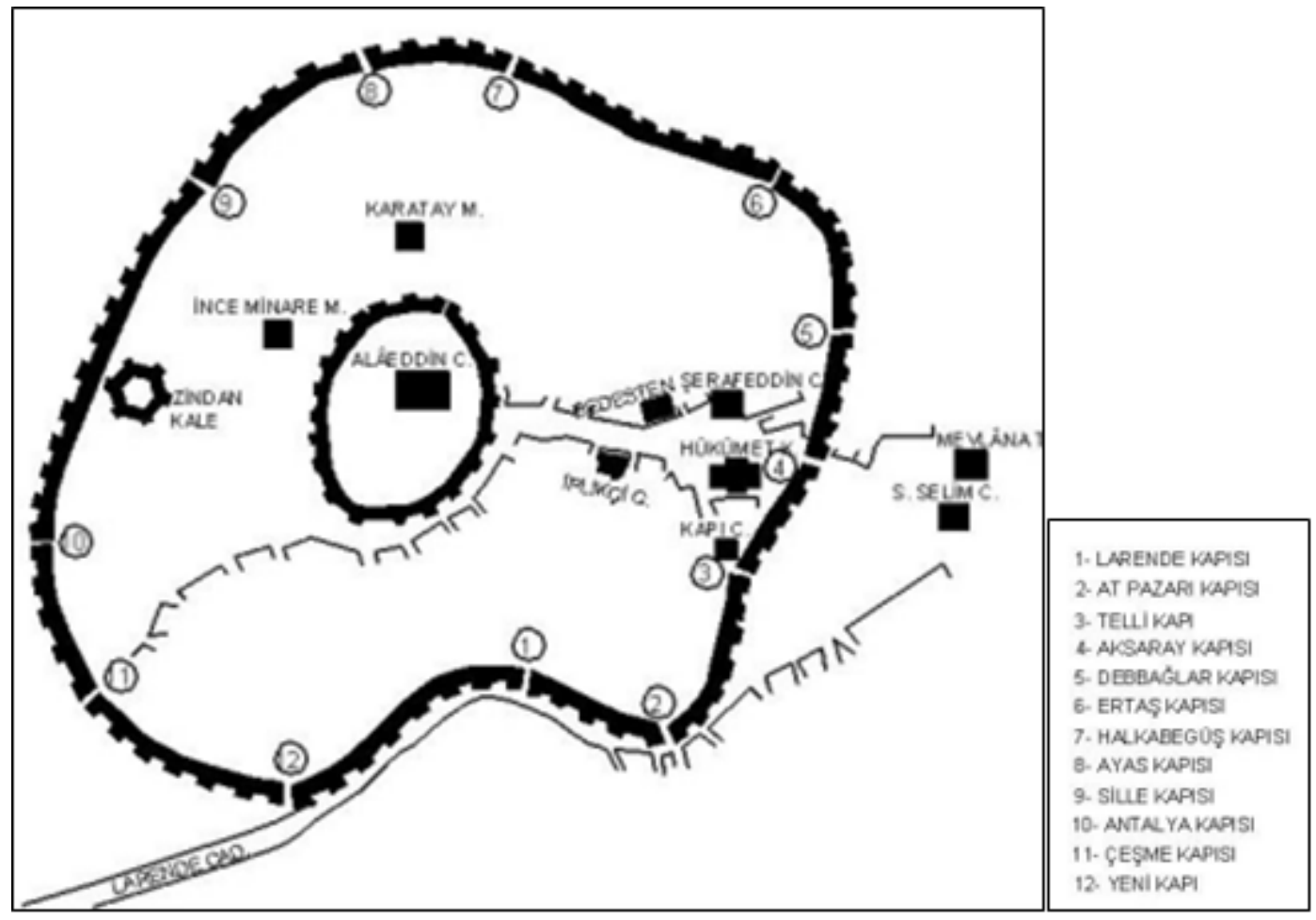

Şekil 1. Konya Bedestenin Sur İçerisindeki Konumu (Baş ve Bozkurt, 2003) 


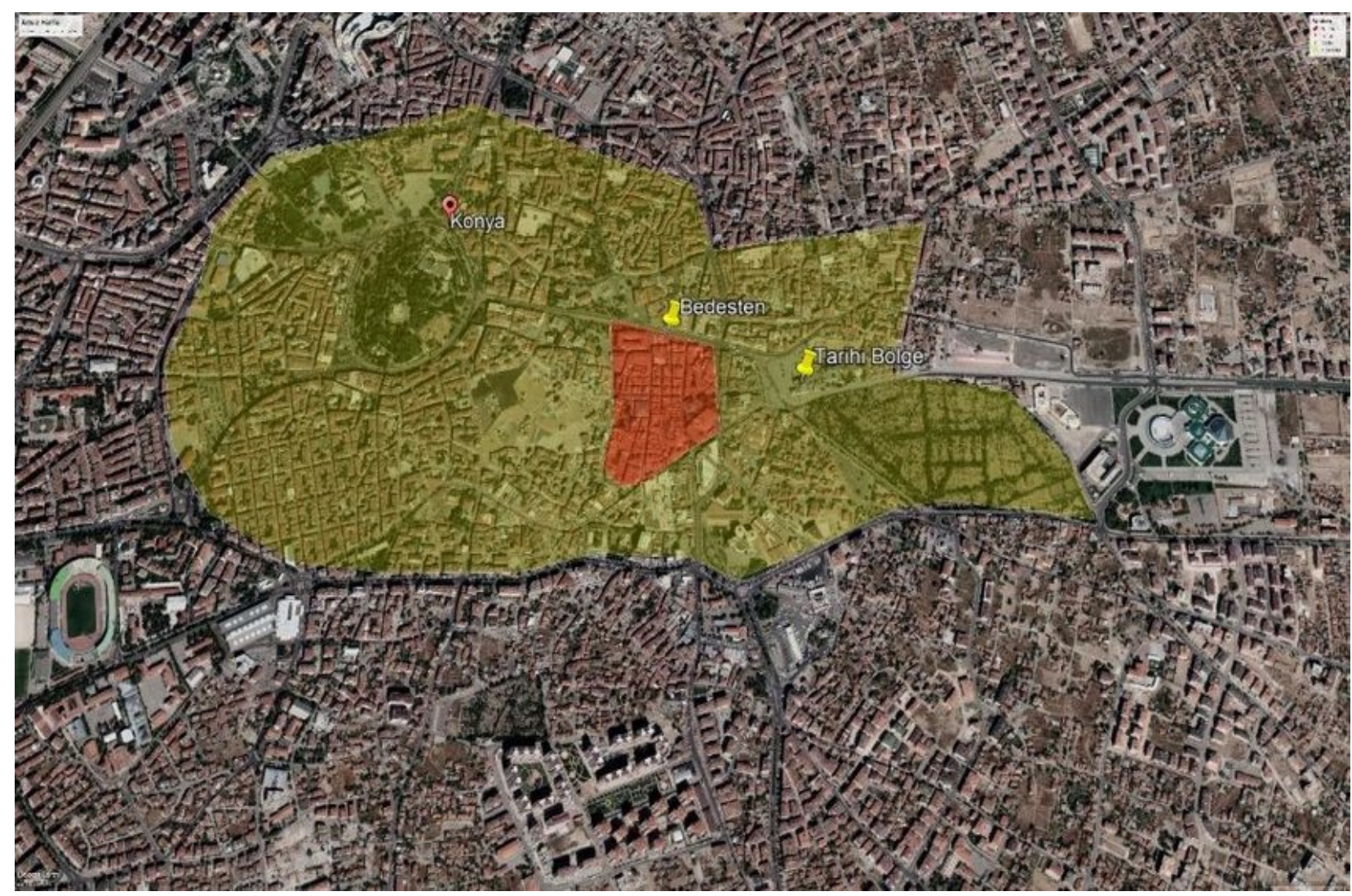

Şekil 2. Konya tarihi Bedesten Çarşısı'nın şehrin kalbindeki konumu (Ergenç, 1995)

Konya Bedesten Çarşı, kendine özgü özellikleri barındıran dükkanları ve dükkanların cadde ile olan ilişkileri, insan ölçeğindeki formu ve insana uygun oranları ile geleneksel bir karaktere sahiptir. Bunun yanı sıra Kapı Camii, Aziziye Camii, Bulgur Tekke Camii gibi anıtsal yapılara zemin oluşturarak bu kültür varlıklarını daha etkin kılmaktadır (Uysal, 2004).

Selçuklu ve Osmanlı dönemlerinin karakteristik özelliklerini taşıan geleneksel bedesten çarşı, geleneksel yapıya uymayan yeni kent yapılanması ve çok katlı yeni yapıların inşa edilmesi sonucunda Cumhuriyet döneminde özgün dokusunu kaybetme tehlikesiyle karşı karşıya kalmıştır. Bu kapalı çarşının fiziki yapısı çıkan yangınlar sonucunda değişme uğramıştır. En büyük yangın 1867'de gerçekleşmiştir (Tutal ve Topcu, 2018).

\section{Osmanlı Kent Sisteminde Çarşı ve Gelişimi}

16. yüzyılda Osmanlı kentlerindeki nüfusun hızla artması ve dünya ticaretinde yaygın olan "gezginci tüccarların" yerini "yerleşik tüccarların" alması kentin ticari yapısında dönüşüme neden olmuştur. Bu sistemin oluşumunda Osmanlının hukuki düzenlemelerinin önemli payı da bulunmaktadır. Osmanlı hukukuna göre, bir yerin kent sayılabilmesi için sürekli ticaretin yapıldığı bir ticaret yeri ve cuma namazının kılındığ 1 bir cami olması gerekir (Kejanlı, 2010). Dolayısı ile Osmanlı döneminde kalıcı ve örgütlenmiş ticari alanların artması ve gelişmesi önem kazanmaya başlamıştır.

17. ve 18. yüzyıllara gelindiğinde Türk kentleri için tanımlanan mekânsal düzen, Osmanlı İmparatorluğu'nun kuruluş ve yükselme dönemlerinde değişiklik göstermiştir. Mekânsal düzende yaşanan bu değişimler Dumont ve Georgeon'a göre:

Anadolu'da Selçuklu ve Osmanlı Kent Yapısında Çarşının Konumu ve Mekânsal Kurgusu Üzerine Bir İrdeleme

Journal of Urban Academy | Volume: 14 Issue: 2 | ISSN: 2146-9229

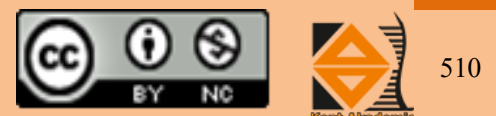


- İnsan-toprak ilişkilerindeki değişimler,

- Miri toprak düzeninde çözülmeler,

- Dünya üzerinde ticari sistemde ve ulaşım teknolojilerindeki değişimler,

- Anadolu'daki isyanların yarattığı dönüşümler olmak üzere dört madde ile ifade edilmiştir (Dumont ve Georgeon, 1999)

$\mathrm{Bu}$ değişimlerin sonucunda 18. yüzyıl Osmanlı kentleri için yapısal ve kültürel anlamda büyük değişikliklerin yaşandığ 1 bir dönem olmuştur. Ayrıca bu dönem, İran ve Doğu kültürü ile olan fikir ve teknik ticaretin azalması sonucu Avrupa ile ilişkilerin arttı̆̆ı bir dönemdir (Tanyeli, 1986).

19. yüzyılda ise Osmanlı devletinin zayıflamasıyla ürün fazlası kontrolü ortadan kalkmış, sabit üretim teknolojisi için ulaşım teknolojisinde ve ayrıca dış ticaret ilişkilerinde değişiklikler başlamıştır. 19. yüzyılın ikinci yarısından itibaren Avrupa ülkeleri çeşitli tarımsal ürün ve hammadde üreten Anadolu'nun iç bölgelerine yatırım yapmaya başlamıştır. $\mathrm{Bu}$ tarz yatırımlar bu bölgeler ile kıyı kentleri arasında gelişmiş ulaşım ağlarının kurulmasına da neden olmuştur (Dumont ve Georgeon, 1999). Bu dönemde, Avrupa ile ticari ilişkilerin artması ve hatta ticaretin bazı kentlerde gelişimiyle birlikte batı mimarisinden etkilenmiş ticaret yapıları inşa edilmesine rağmen geleneksel ticari yapılar ve özellikle en önemlisi olan çarşılar eski önemini hiçbir zaman kaybetmemiştir (Cerasi, 1999).

Osmanlı döneminde mesleğe göre çarşı ve pazarların dağılımında belirli bir düzen görülse de çarşıların merkezinde çoğunlukla cami veya bedesten bulunmaktadır (Ülgener, 1991; Halaç ve Ergün, 2020). Merkezin çevresinde de ticari faaliyetlerin gerçekleştirildiği alanlar bir kuşak oluşturmaktadır. Bu kuşak aynı zamanda konaklama, dinlenme, ibadet, yeme-içme ve kişisel hizmetler gibi işlevleri olan alanları da içermektedir. Üretim alanları ise çarşı sisteminin en dış kuşağında yer almaktadır (Şahinalp ve Günal, 2016). Dolayısı ile Osmanlı kentlerindeki çarşıların kentsel doku içindeki konumunu belirleyen en önemli faktörler; toplumun ekonomik, kültürel, sosyal ve dini yapısının dinamikleri olmuştur (Tanyeli, 1986).

\subsection{Selçuklu Döneminde Merkez-Çarşı Gelişimi}

Osmanlı, ilk kuruluşundan itibaren karşıt yönlü bir gelişim süreci içerisinde oluşmuştur. Bir taraftan Bizans duvarlarıyla sınırlandırılan 'eski çekirdek', kent alanının genişlemesi sonucu surların dışına taşmıştır. Diğer taraftan ise mevcut ana yerleşim bölgesine yakın olmayan 'yeni kentsel çekirdek' oluşmaya başlamıştır. Kentin büyümesi ve gelişmesi, bu yeni çekirdeklerin yoğunlaşması ve bunların eski kentsel alana eklemlenmesiyle gerçekleşmiştir (Aktüre, 1987).

Erken Osmanlı döneminde tarım dışı faaliyetler ve ticari amaçlı üretimin oluşum dönemleri, şehrin geleneksel mekan organizasyonunda bir kademelenme oluşturmuştur. Kentteki bu kademelenme:

- Kentsel yönetim ve denetim etkinliğinin odaklandığı merkez bölge,

- Merkezin yanında veya yakın çevresinde zanaatkâr, esnaf eylemlerinin odaklandığı iş bölgesi,

- $\quad$ Konut bölgeleri,

- Mevcut ticari sistemin dışında olan grupların bir takım ekonomik faaliyetlerin yer aldığı bölge olmak üzere dört ayrı bölge olarak sıralanabilir (Tekeli, 1985).

Osmanlı kentlerinde ilk çekirdeği oluşturan cami ve çarşıların konumlandığı merkez, tüccarların toplumsal ve ekonomik etkinliklerini gerçekleştiği ana mekanlardır. Ticari faaliyetlerin gerçekleştiği bu merkezi bölge, kentlerin kale yerleşkesine yakın inşa edilmiştir. Çarşının kaleye yakın inşa edilmesinin en önemli nedeni, kentin ekonomi kalbi olan bu mekânın güvenliğini sağlamak olmuştur (Kejanlı, 2010). Osmanlı kent yapısında, ticari faaliyetlerin yanı sıra sanayi faaliyetlerinin gerçekleştiği mekanlar ve yoğun kullanılan kamusal mekanlar da çarşı ve kale ilişkisine göre konumlandırılmıştır (Tanyeli, 1986). Kentler, 15. ve 16. yüzyıl Osmanlı dönemi çarşılarının fiziksel yapısında gelişen 
bedestenler ile merkez çarşılarına yakın yayılım göstermeye başlamış ve çarşı-merkez noktası konumu daha çok önemsenmiştir (İnan, 1996).

17. yüzyıla kadar kent merkezindeki çarşının en önemli unsurları olan bedestenler ve hanların fiziksel dokuları, gelişim gösterdikleri alan içerisinde kalmış ve farklılaşma göstermemiştir. Ticari ve küçük sanatlarla ilgili faaliyetlerin gelişimi de bedesten ve hanlar ile benzer şekilde devam etmiştir (Ortaylı, 1977). Bedestenlerin etrafinda belirli ticari faaliyetlerin gerçekleştirildiği ve üretim mekanlarının bulunduğu sokaklar oluşmuştur. Hanlar da konaklama amacıyla bedestenlerin yakınında inşa edilmiştir.

Kent merkezleri, kentleşme oranının daha düşük olduğu sanayi öncesi dönemlerde, geleneksel işletmelerin bulunduğu, küçük zanaat faaliyetlerinin gerçekleştirildiği, ticaretin yoğunlaştığı ve alışverişin yapıldığı yerlerde konumlanmıştır. $\mathrm{Bu}$ dönemde konut ve işyerlerinin belirgin bir farklılık göstermemesi sonucu kent merkezi; ticaret, yönetim ve denetim işleriyle uğraşan kesimin işyerinin bulunduğu alan olmakla birlikte aynı zamanda yaşadıkları konutlarında bulunduğu yer olmuştur (Aktüre, 1997). Bu sebeple, sanayi öncesi dönemde kentin ticari merkezleri, günümüz ifadesi ile 'karma kullanımlı alanlar' olarak değerlendirilebilir.

19. yüzyılda kentleşmenin artışıyla beraber Anadolu kentlerinin dış ticarete açıldığı bir dönem olmuştur. Dış ticarete açılma, kentin sosyo-ekonomik yapısında meydana getirdiği değişimle beraber Anadolu kentlerini, sanayi üretiminde hızla ilerleyen Avrupa'nın işlenmiş ürünlerinin satış pazarına dönüştürmüştür (Ertuğrul, 2009). Bu değişimde büyük rol oynayan yabancı tüccarlar ve aracıları, bu sistemi Anadolu kentlerine yerleştirerek yerel üretimin çöküşüne yol açmışlardır. Ayrıca, çeşitli sosyal grupların da mekânda ayrışmasına neden olmuştur. Bu durum, kentin ve onun en önemli unsurlarından biri olan çarşının morfolojik yapısında yeni bileşenlerin oluşmasına yol açmıştır (Kejanlı, 2010).

Kentlerdeki bahsi geçen sosyal ve mekânsal ayrışmanın sonucu olarak 19. yüzyıl sonuna gelindiğinde, iki farkı sosyal grubun işyerlerinin yer aldığı mekanların kentte iki farklı ticari merkez ortaya çıkardığı görülmektedir. 19. yüzyılın sonuna kadar geleneksel çarşılarda konumlarını ve ticari yapıdaki önemlerini koruyan yerel esnaf ve zanaatkarlar dışında, kentte oluşan yeni sosyal kesimin ticaret ve iş yeri olarak tanımlanabilen "yeni ticari merkez" anlayışı oluşmaya başlamıştır. Böylelikle kent içi "yeni ticari merkezler" inşa edilmiş ve bu yeni ticari merkezin içinde iş hanları, bankalar, yeni dükkanlar, oteller vb. gibi birden çok işlevin birlikte yer alabildiği yapı tipleri ortaya çıkmıştır (Faroqhi, 2000).

19. yüzyılda özellikle batı ülkeleriyle artan ticari ilişkilerin en yoğun yaşandığı yer İstanbul kentidir. Özellikle Avrupa ticari sistemine uygun olarak gelişen yeni ticari sisteme göre farklı işlevlerde ticari yapılar ortaya çıkmaya başlamıştır. Bu dönemin en önemli örneklerinden biri İstanbul'da Galata-Pera bölgesinde yer alan ticari yapılardır. Bunun yansıra, yaklaşık olarak 1860'lı yıllardan sonraki süreçte tarihi yarımadanın en önemli bölgesi olan Eminönü ve Beyoğlu'nda inşa edilen batı tarzında ticari yapılar ön plana çıkmıştır. En önemli örnekler Sultanhamam Hamdi Bey Geçidi, Mahmut Paşa Abud Efendi Hanı, Sultanhamam Hocopoulo Hanı, Galatasaray'da Çiçek Pasajı ve Yeni Avrupa Pasajı olarak gösterilebilir. Ttüm Osmanlı topraklarında özellikle İzmir, Selanik, Beyrut gibi dış ülkelerle ticaretin yoğun olarak yapıldığı bölgelerin özellikle kent merkezlerinde; dükkânlar, işhanları, büyük mağazalar bankalar, pasajlar ve bürolar inşa edilmiştir (Ertuğrul, 2009).

\section{2. İstanbul Kapalıçarşı}

İstanbul Kapalıçarşısı dünyanın en eski ve en büyük çarşılarından biridir. Çeşitli sokaklar üzerinde konumlandırılmış yaklaşık 4000 dükkân ve farklı işlevdeki önemli yapılardan oluşmaktadır. Kapalıçarşı merkezinde, iki adet bedesten yer almaktadır. Çarşı kompleksinin iç kısmında yer alan $48 \mathrm{~m}$ x $36 \mathrm{~m}$ boyutundaki Cevahir bedesteninin, Bizans'tan kalma bir yapı olduğu düşünülmektedir. Cevahir bedesteninde 15 ayrı bölüm bulunmaktadır. Bu bölümlerin her biri kubbe ile örtülmüştür (Şekil 3). Bu çarşının ikinci önemli bedesteni olan Sandal bedesteni ise 1460 yllında Fatih Sultan Mehmet tarafından yaptırıldığı bilinmektedir ve Cevahir bedestenine benzer şekilde kubbe örtülü bir tasarıma sahiptir (Akozan, 2011).

İstanbul Kapalıçarşısı; Kuyumcular, Nuruosmaniye, Sepetçihan, Takkeciler gibi çeşitli kapılardan, Altuncular, Halıcılar, Kavaflar gibi farklı sokaklardan ve Yolgeçen, Zincirli, Rabia ve Bodrum gibi birçok hanlardan oluşmaktadır (Şekil 4). 


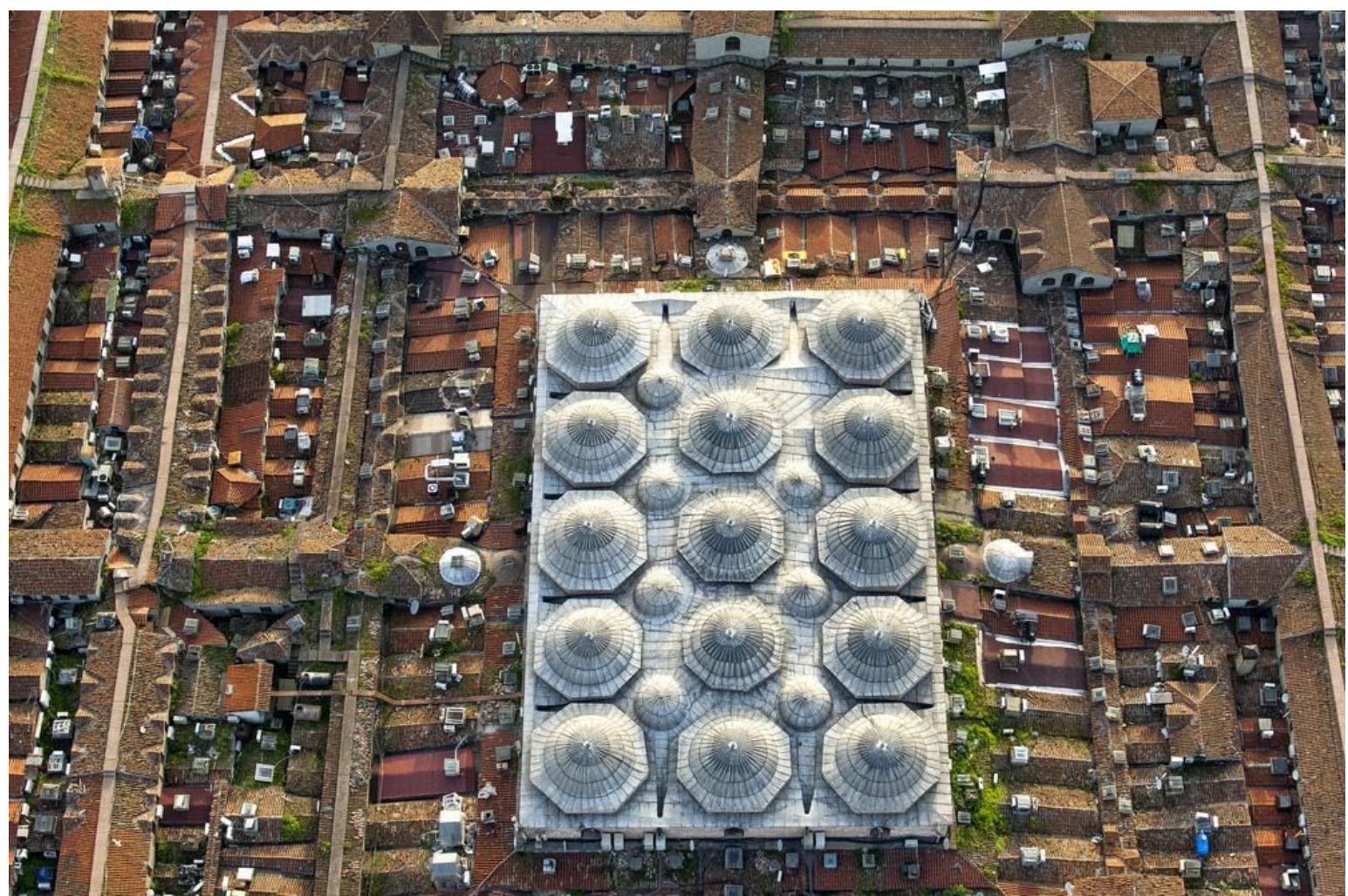

Şekil 3. Cevahir Bedesteni ve kapalı çarşı üst görünüşü (Elit World, 2020)

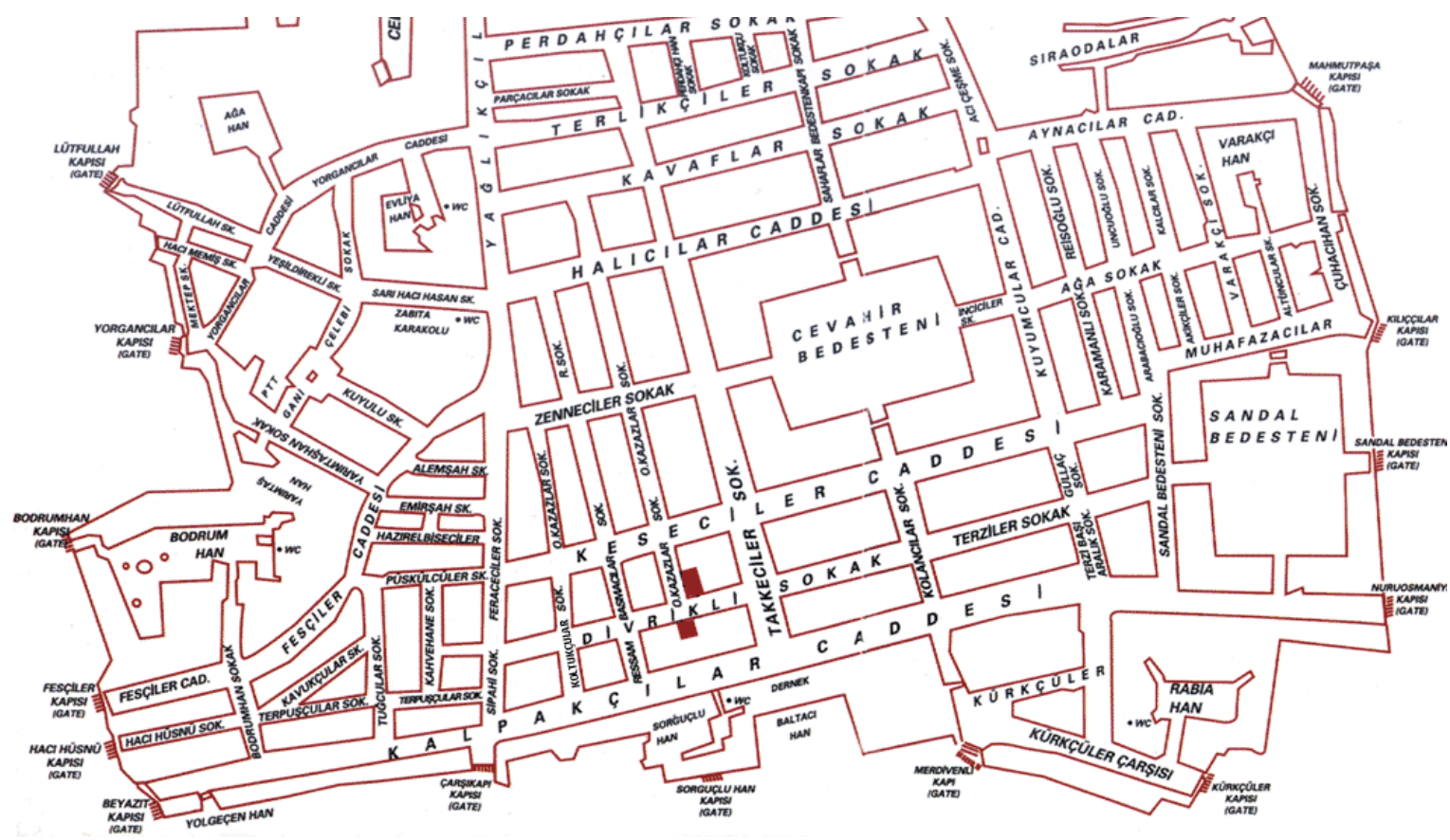

Şekil 4. İstanbul kapalı çarşı planı (Dedeoğlu, 2007)

Anadolu'da Selçuklu ve Osmanlı Kent Yapısında Çarşının Konumu ve Mekânsal Kurgusu Üzerine Bir İrdeleme

Journal of Urban Academy | Volume: 14 Issue: 2 | ISSN: 2146-9229 


\subsection{Bursa Kapalıçarşı}

Erken Osmanlı döneminin en önemli ve ilk çarşı örneklerinden biri Bursa çarşısıdır. Bursa kenti 13. yüzyıldan itibaren doğu ve batıyı birbirine bağlayan önemli ticari yolların geçtiği bir yer olarak ticari açıdan son derece önemli bir kent olmuştur (Yenal, 1996). Bu nedenle kentin ticari merkezi, kentin en önemli unsuru olmuştur ve farklı tarihsel süreçlerde çok fazla yapısal değişiklikler geçirmiştir. Kentin ticari alanının Osmanlı dönemi değişimlerinden en önemlisi, 14. yüzyılda şehrin kale surları dışında, bedesten merkezli bir çarşının oluşması olmuştur (Tekeli, 1999). Çarşılar, hanlar, pazarlar, bedesten hamamlar vb. yapıların inşa edilmesi ile 14. yüzyılda Bursa tarihi ticaret merkezi oluşmaya başlamış ve 16. yüzyıla kadar gelişim göstermiştir (Tanyeli, 1987).

14. yüzyılın ilk yarısında, kentin ticari merkezi kalenin doğusunda kurulmuştur. Ticaret merkezini oluşturan ilk yapılar Orhan Gazi’nin yaptırdığı cami, imaret, han ve hamamdan oluşan kültürel ve ticari yapılardır (Tekeli, 1999). Daha sonraki dönemlerde sultanların inşa ettirdikleri hanlarla, ticaret merkezinin gelişimi devam etmiştir. İpek Han, Geyve Han ve Yeni İpek Hanın 15. yüzyıl başlarında doğu-batı yönlerinde; 15. yüzyıl sonlarında ise Koza Han güney ve Fidan Han kuzey yönünde inşa edilmiştir. Böylelikle uzun çarşı aksı oluşmaya başlamıştır (Şekil 5). İlerleyen zamanlarda bu aksın her iki tarafında çeşitli ticari mekanlar inşa edilmiş ve daha sonraki zamanlarda bu alanın üstü örtülerek Bursa Kapalıçarşı'sının ilk bölümleri olarak bilinen Sahaflar ve Aktarlar Çarşıları ortaya çıkmıştır (Eriçok, 2014).

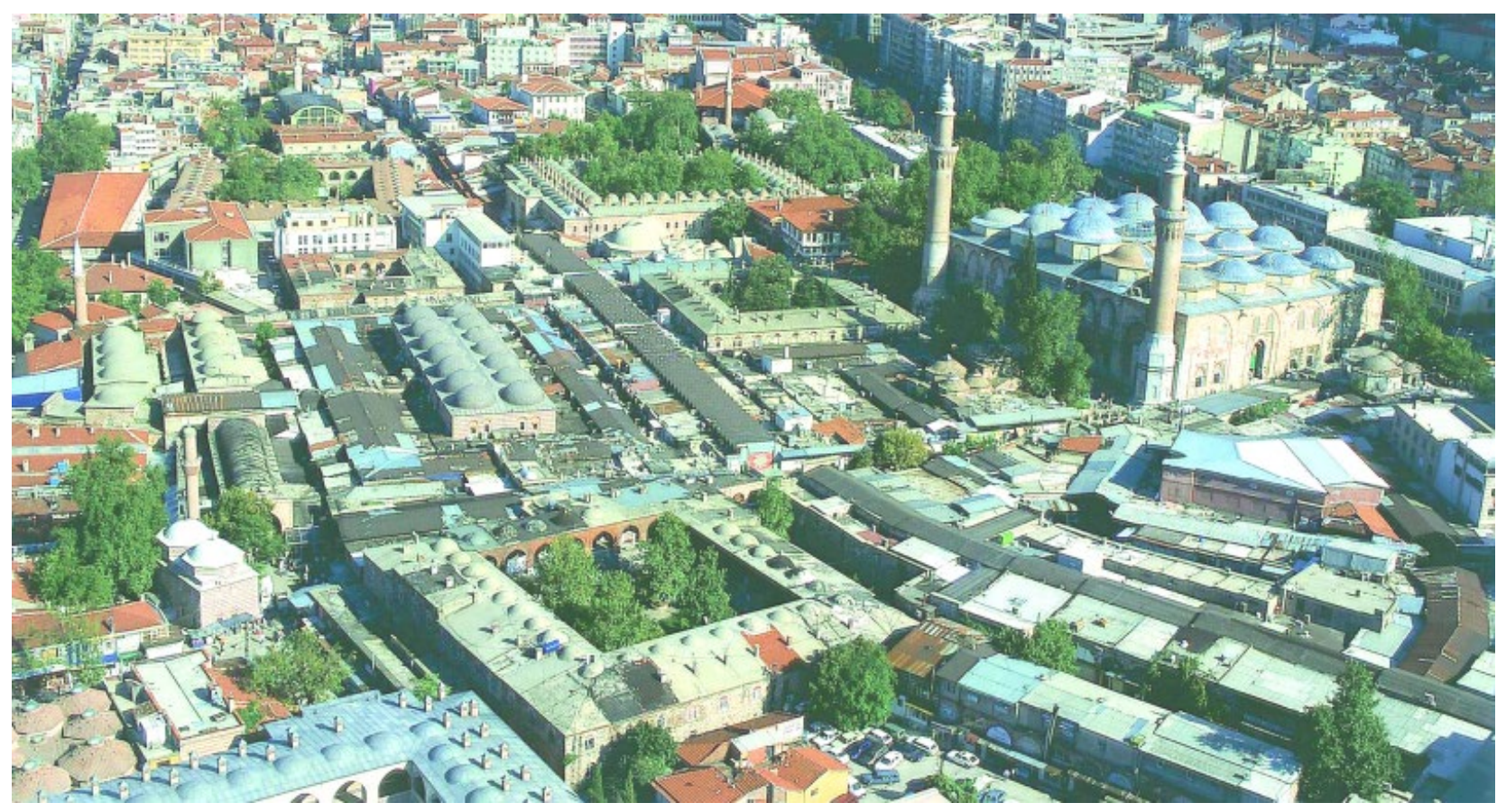

Şekil 5. Tarihi Bursa çarşısının genel görünümü (Dede, 2010)

Bursa Kapalıçarş̧ gelişimi devamında 16. yüzyıla gelindiğinde, ticari birimler ve hanların sayısı artmıştır. Dolayısı ile farklı malların ticareti ve farklı dallarda zanaat faaliyetler ile uzmanlaşmış çarşılar ayrışıı̧ıtır (Tekeli, 1999). Bursa çarşı yapısının zaman ile düzenli bir sosyal ve fiziksel yapıya sahip olmaya başladığı bilinmektedir.

17. ve 18. yüzyıllara gelindiğinde ise çarşı yapısında önemli bir değişim yaşanmadığı görünmektedir. 19. yüzyılda ise fiziksel bütünlük ve mekânsal yapı açısından Bursa ticari merkezine yapılan ilk müdahale, uygulanan imar çalışmaları sonucunda gerçekleşmiştir. 20. yüzyılda ise bu tarihi mekanda meydana gelen en önemli değişim 1958 yılında meydana gelen yangın ve sonrasındaki süreçte yaşanan değişimler olmuştur (Eriçok, 2014). 


\section{SONUÇ:}

Bu çalışma; Selçuklu ve Osmanlı dönemlerine dair ekonomik yapı, ticaret ve ona hizmet eden mekanların kurgusu, kent planlama mantığı ve bu düzen içinde ticari merkez ve onun en önemli öğesi olan çarşının konumu ve işlevlerini incelenmiştir. Bu inceleme sonucunda Selçuklu dönemi ve Osmanlı devletinin 18. yüzylla kadar olan döneminde yakın benzerlikler tespit edilmektedir. Bu benzerlikler kısaca şu şekilde anlatılabilir:

- Her iki dönemde de çarşı yapısı sur içine alınarak her türlü saldırıya karşı güvenliği sağlanmıştır.

- Yapısal bazı farklılıklara rağmen genel biçimsel kurgu her iki çarşı tipinde de benzerdir. Örneğin Her durumda çarşının kalbi hem Selçuklu ve hem Osmanlı dönemde bedestendir.

- Her iki çarşı tipinde ticaret dışında sanayi faaliyetlerine dair imalathaneler de bulunmaktadır.

- Her iki çarşı tipinde de belirli ekonomik faaliyetler yapan sınıfların bir arada örgütlendiği şekilde ticari mekân oluşumları görülmektedir.

Osmanlı döneminde hem yerli hem de yabancı tüccar ve üreticilerin mal ticareti için çarşı içinde çeşitli özel ticari binalar yapılmıştır. Selçuklulardan kalan ticari binalar onarılıp kullanılırken, yeni ticari binaların eklenmesiyle çarşıların ekonomik potansiyeli güçlendirilmiştir (Şahinalp ve Günal, 2016). Aslında Osmanlı çarşıları Selçuklu çarş1 sisteminin devamında gelen ve onu geliştiren bir mantıkta oluştuğu için hem fiziksel yapı hem de işleyiş ve iç mekan kullanımları açısından çok fazla farklılık görünmemektedir. Fakat Selçuklu döneminde günümüze tamamen o döneme ait olan çarşı yapıları çok sayıda bulunmadığı nedeniyle Selçuklu dönemindeki çarşılar Osmanlı çarşılarına kıyasen daha dayanıksız malzemelerden yapıldığı doğrultusunda tahmin yürütülmektedir. Bunun dışında Selçuklu dönemi ve Osmanlının özellikle 18.yüzyılından sonraki yıllarında tüm dünyada gerçekleşen birtakım değişimlerin Osmanlı devletinin siyasi ve kültürel yapısını da etkilemekle birlikte Selçuklu dönemine kıyasla kentin ekonomik kalbi olan çarşı unsuru ve onun işleyişiyle ilgili birtakım farklılık da ortaya çıkmıştır. Bu araştırma kapsamında gözetilen farklılıklardan bazıları şu şekilde ifade edilebilir:

- Selçuklu döneminde başka konularda olduğu gibi ticari kültür ve buna dair mekân organizasyon açısından daha çok İran ve doğu kültürü etkisi görülmektedir. Fakat Osmanlı döneminde, 18. yüzyıl Osmanlı kentleri için önemli yapısal ve kültürel değişimlerin yaşandığ kültürüyle fikir ve teknik ticaretin azaldığı, batı ile ilişkilerin arttığı bir dönemdir.

- Selçuklu döneminde çarşı, kentin tek ekonomik kalbi olarak hizmet etmiştir. Bu düzen Osmanlı devletinin belirli dönemlerinde de benzer şekilde devam etmiştir. Ancak 18. yüzyıldan sonraki dönemde, dünya tarihinden etkin olan sanayileşme ve Osmanlı devletinin zayıflaması sonucu Avrupa ülkelerinin ticari mallarının Anadolu çarşılarına girmesiyle birlikte ticari yapıda gerçekleşen değişimler Çarşı ve onun kentteki kültürel konumuna da yansımaya başlamıştır. Öyle ki, 19. yüzyılının sonuna gelindiğinde bu döneme kadar kentin tek ve en güçlü ana damarı olan çarşılara paralel olarak yeni ortaya çıkan sosyal statü deki insanların iş yeri olarak ortaya çıkan "yeni ticari merkez" görülmeye başlamıştır.

Anadolu Selçuklu kentlerinin mekânsal ögeleri Orta Asya, İran ve Türk-İslâm kültürlerinden gelen birikimin yansıra, Anadolu'da devralınan Bizans yerleşim kültürü ile harmanlanması sonucu zengin kentler ortaya çıkmıştır. Her kentin ticaret ve ekonomisinin kalbinin attığı yer olan çarşı unsuru da bu kültürel birikimlerin en önemli mekânsal yansımalarından sayılmaktadır. Bu mekânsal biçimlenme sürecinden, Osmanlı dönemine gelindiğinde de çarşı unsuru, kentsel yerleşim sistemi ve ulaşım ağı içerisindeki işlevsel kimlik ve mekânsal niteliklerini koruyarak, Osmanlının geniş alanda hüküm sürdüğü coğrafyalardan aldığı kültürel, mimari ve ekonomik zenginlikler de katarak sürdürmüştür. Dolaysıyla, bu kadar fazla kültürel ve tarih değer içeren çarşıların yaşatılması ve canlılığını kaybetmemesi adına ilk önce bu değerli yapıları üzerine yeterli derece de araştırmaların yapılması ve daha sonra da tanıtılması ve korumasına yönelik gerekli adımların atılmasına özen gösterilmelidir. 


\section{Etik Standart ile Uyumluluk}

Çıkar Çatışması: Herhangi bir çıkar çatışmasının olmadığını beyan ederiz.

Etik Kurul İzni: Bu çalışma için etik kurul iznine gerek yoktur.

Finansal Destek: Finansal destek bulunmamaktadır.

\section{KAYNAKÇA:}

Akozan, F. (2011). İstanbul'un Kapalı Çarşısı. Tarih Dergisi, 0 (32), 759-770.

Aktüre, S. (1987). Mimarbasi Sinan and the Building Policies of the Ottoman State. A. Carucci (Ed.), Environmental Design: Journal of the Islamic Environmental Design Research Centre 1-2, 98-105. Roma.

Aktüre, S. (1997). Anadolu’da Bronz Çă̆ı Kentleri. İstanbul: 2.Baskı, Tarih Vakfı Yurt Yayınları.

Baş, A. ve Bozkurt, D. (2003). Konya Bedesteni. Selçuk Üniversitesi Sosyal Bilimler Enstitüsü Dergisi, $507-529$.

Cerasi, M. (1999). Osmanlı Kenti, Osmanlı Imparatorluğu’nda 18. ve 19. yüzyıllarda Kent Uygarlığı ve Mimarisi. (E. Işın, çev.). İstanbul: Yapı Kredi Yayınları.

Cezar, M. (1983). Typical Commercial Buildings of The Ottoman Classical Period And The Ottoman Construction System. İstanbul: Türkiye İş Bankası Kültür Yayınları.

Dede, R. (2010). Bursa Tarihi Kapalı Çarşı'da Kentsel Dış Mekan Organizasyonu Açısından Analitik Bir Inceleme. (Yayımlanmamış yüksek lisans tezi). Uludağ Üniversitesi Fen Bilimleri Enstitüsü, Bursa.

Dedeoğlu, R. (2007). Punto, http://punto-punto.blogspot.com/2007/01/meraklsna-kapalar-plan.html adresinden alındı (21.07.2020).

Dumont, P. ve Georgeon, F. (1999). Modernleşme Sürecinde Osmanlı Kentleri, 2. Baskı, Çeviren: A. Berktay, Tarih Vakfi. İstanbul: Yurt Yayınları.

Elit World. (2020). Kapalı Çarşı'nın Tarihi Hikayesi. https://www.eliteworldhotels.com.tr/blog/kapali-carsinin-tarihihikayesi.55.aspx adresinden alındı (28.07.2020).

Ergenç, Ö. (1995). Osmanlı klasik dönemi kent tarihçiliğine katkl: XVI. yüzyılda Ankara ve Konya (1). Ankara Enstitüsü Vakfi.

Eriçok, A. K. (2014). Bursa Tarihi Ticaret Merkezinde 16. Yüzyıldan Günümüze Ticari Fonksiyonların Değişimi. Planlama Dergisi, 24 (3), 173-181.

Ertuğrul, A. (2009). XIX. Yüzyılda Osmanlı'da Ortaya Çıkan Farklı Yapı Tipleri. Türkiye Araştırmaları Literatür Dergisi, (13), 293-312.

Faroqhi, S. (2000). Osmanlı'da Kentler ve Kentliler, İstanbul: Tarih Vakfı Yurt Yayınları.

Halaç, H.H. ve Ergün, R. (2020). Anadolu bedestenlerinin mevcut durumları üzerine bir inceleme, Kesit Akademi, 6(23), 130-148

İnan, K. (1996). Bedestenlerin Türk Ticari Mimarisindeki Yeri ve Trabzon Bedesteni. Osmanlı Tarihi Araştırma ve Uygulama Merkezi Dergisi OTAM, 119-133.

Kejanlı, D. (2010). Anadolu'da Selçuklu ve Osmanlı Dönemlerinde Kent Sistemi, Kale ve Merkez-Çarşı gelişimi, $e$ Journal of New. E-Journal of New World Sciences Academy, 5 (3), 287-303. 
Ortaylı, İ. (1977). İstanbul'un mekansal yapısının tarihsel evrimine bir bakış. Amme İdaresi Dergisi, 10(2), 77-97.

Özcan, K. (2005). Anadolu'da Selçuklu Dönemi Yerleşme Sistemi ve Kent Modelleri. (Yayımlanmamış doktora tezi), Selçuk Üniversitesi Fen Bilimleri Enstitüsü, Konya.

Özcan, K. (2006). Anadolu-Türk Kent Tarihinden Bir Kesit: Selçuklu Döneminde Anadolu-Türk Kent Modelleri, Bilig, 38, 161-184.

Özcan, K. (2010). Erken Dönem Anadolu-Türk Kenti Anadolu Selçuklu Kenti ve Mekânsal Ögeleri, Bilig, 55, 193220.

Özdeş, G. (1998). Türk çarşıları. Ankara: Tepe Yayınları.

Şahinalp, M. S. ve Günal, V. (2016). Osmanlı Dönemi Anadolu Şehirleri Çarşı Sisteminin Fonksiyonel Analizi. Electronic Turkish Studies, 11(8). 335-360.

Tabakoğlu, A. (1985). Gerileme Devrine Girerken Osmanlı Maliyesi, Dergâh Yayınları, İstanbul.

Tanyeli, U. (1986). Anadolu-Türk Kentinde Fiziksel Yapının Evrim Süreci (XI.-XV. Yüzyıllar), (Yayımlanmamış doktora tezi), İstanbul Teknik Üniversitesi Fen Bilimleri Enstitüsü, İstanbul.

Tanyeli, U. (1987). Anadolu Türk Kentinde Fiziksel Yapının Evrim Süreci: 11-15. yüzyıl. İstanbul: İTÜ Yayını.

Tekeli, İ. (1985). Tanzimat'tan Cumhuriyet'e Kentsel Dönüşüm, Türkiye Ansiklopedisi, Cilt 4, İstanbul: İletişim Yayınları.

Tekeli, İ. (1999). Bursa'nın Tarihinde Üç Ayrı Dönüşüm Dönemi. 11. Uluslararası Yapı Yaşam Kongresi, Osmanlı Devletinin Kuruluşunun 700. Yıldönümünde Bursa ve Yöresi, Bursa, 6-8 Mayıs. 7-28.

Tutal, O., ve Topcu, M. (2018). Thinking with Universal Design in Historical Environment. International Journal of Architecture \& Planning, Cilt 6, Special Issue, 63-80.

Uysal, M. (2004). Tarihi merkezlerde ticaret mekanlarının değişim/dönüşüm analiz yaklaşımı; Konya, Kayseri, Sivas örneği. (Yayımlanmamış doktora tezi), Selçuk Üniversitesi Fen Bilimleri Enstitüsü, Konya.

Ülgener, S. (1991). İktisadî Çözülmenin Ahlak ve Zihniyet Dünyası, İstanbul, Der Yayınları.

Yenal, E. (1996). Osmanlı Başkenti, Osmanlı Kenti Bursa, Bir Masaldı Bursa, E. Yenal (Ed.). Yapı Kredi Yayınları.

Yenen, Z. (1987). Vakıf Kurumu İmaret Sistemi Bağlamında Osmanlı Dönemi Türk Kentlerinin Kuruluş ve Gelişim Illkeleri, (Yayımlanmamış doktora tezi), İstanbul Teknik Üniversitesi Fen Bilimleri Enstitüsü, İstanbul.

Yılmazçelik, İ. (1995). XIX. Yüzyılın İlk Yarısında Diyarbakır (1790-1840). Ankara: Türk Tarih Kurumu Yayını. 